\title{
Investigating the use of secondary organic aerosol as seed particles in simulation chamber experiments
}

\author{
J. F. Hamilton ${ }^{1}$, M. Rami Alfarra ${ }^{2,3}$, K. P. Wyche ${ }^{4}$, M. W. Ward ${ }^{1}$, A. C. Lewis ${ }^{1}$, G. B. McFiggans ${ }^{3}$, N. Good ${ }^{3, *}$, \\ P. S. Monks ${ }^{4}$, T. Carr ${ }^{4}$, I. R. White ${ }^{4}$, and R. M. Purvis ${ }^{1}$ \\ ${ }^{1}$ Department of Chemistry, University of York, Heslington, York, YO10 5DD, UK \\ ${ }^{2}$ National Centre for Atmospheric Science (NCAS), School of Earth, Atmospheric and Environmental Sciences, University of \\ Manchester, Manchester, M13 9PL, UK \\ ${ }^{3}$ Centre for Atmospheric Science, School of Earth, Atmospheric and Environmental Sciences, University of Manchester, \\ Manchester, M13 9PL, UK \\ ${ }^{4}$ Atmospheric Chemistry Group, Department of Chemistry, University of Leicester, Leicester, LE1 7RH, UK \\ * now at: Laboratoire de Météorologie Physique, Blaise Pascal Univ., Clermont-Ferrand, 63000, France
}

Received: 13 October 2010 - Published in Atmos. Chem. Phys. Discuss.: 27 October 2010

Revised: 28 March 2011 - Accepted: 18 April 2011 - Published: 23 June 2011

\begin{abstract}
The use of $\beta$-caryophyllene secondary organic aerosol particles as seeds for smog chamber simulations has been investigated. A series of experiments were carried out in the Manchester photochemical chamber as part of the Aerosol Coupling in the Earth System (ACES) project to study the effect of seed particles on the formation of secondary organic aerosol (SOA) from limonene photooxidation. Rather than use a conventional seed aerosol containing ammonium sulfate or diesel particles, a method was developed to use in-situ chamber generated seed particles from $\beta$-caryophyllene photo-oxidation, which were then diluted to a desired mass loading (in this case $4-13 \mu \mathrm{g} \mathrm{m}^{-3}$ ). Limonene was then introduced into the chamber and oxidised, with the formation of SOA seen as a growth in the size of oxidised organic seed particles from 150 to $325 \mathrm{~nm}$ mean diameter. The effect of the partitioning of limonene oxidation products onto the seed aerosol was assessed using aerosol mass spectrometry during the experiment and the percentage of $\mathrm{m} / \mathrm{z} 44$, an indicator of degree of oxidation, increased from around 5 to $8 \%$. The hygroscopicity of the aerosol also changed, with the growth factor for $200 \mathrm{~nm}$ particles increasing from less than 1.05 to 1.25 at $90 \% \mathrm{RH}$. The detailed chemical composition of the limonene SOA could be extracted from the complex $\beta$-caryophyllene matrix using two-dimensional gas chromatography $(\mathrm{GC} \times \mathrm{GC})$ and liquid chromatography coupled to mass spectrometry. High resolution Fourier Transform Ion Cyclotron Resonance Mass Spectrometry (FTICR-MS) was used to determine exact molecu-
\end{abstract}

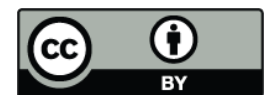

Correspondence to: J. F. Hamilton (jfh2@york.ac.uk) lar formulae of the seed and the limonene modified aerosol. The average O:C ratio was seen to increase from 0.32 to 0.37 after limonene oxidation products had condensed onto the organic seed.

\section{Introduction}

Atmospheric aerosols affect the climate through both direct and indirect radiative processes, however there remain significant uncertainties in the magnitude and variability of effects, arising from limited knowledge on sources, composition, properties, and the mechanisms of their formation (Fuzzi et al., 2006). The gas phase oxidation of biogenic compounds in the atmosphere can result in the formation of lower volatility species which can form biogenic secondary organic aerosol (BSOA), one of the most uncertain factors in the global radiation budget (Intergovermental Panel for Climate Change, 2007). Recent modelling studies of atmospheric aerosols using explicit chemical mechanisms based on results from simulation chamber experiments have shown a significant under-prediction of secondary organic aerosol formation (SOA) when compared to measurements. For example, in their respective studies, Volkamer et al. (2006) and Capes et al. (2009), reported under predictions in modelled SOA by factors of the order 4-15, when compared to measurements. One explanation for this effect is a lack of background particles in traditional smog chamber experiments. In chambers where particle formation occurs by nucleation, there is an induction time for SOA formation as condensable products must exceed saturation vapour pressures. In

Published by Copernicus Publications on behalf of the European Geosciences Union. 
general, owing to the widespread presence of pre-existing condensation surfaces in the real atmosphere, organic nucleation is not widely observed; the more common phenomenon is the propagation of organic aerosol mass via the condensation of oxidized VOC products onto pre-existing aerosols. Better simulation in chamber experiments can therefore be achieved by including background or "seed" particles for oxidised products to partition onto.

It is a criterion of absorptive partitioning theory that all condensed components are miscible across the whole concentration range, and thus the greatest amount of interaction is likely to take place when seed particles have similar properties as the compounds condensing onto them. Historically, most chamber experiments have used inorganic aqueous solutions of ammonium sulphate or sulphuric acid as seed aerosols to study SOA formation (Hallquist et al., 2009), sometimes dried prior to use (e.g. Odum et al., 1997). Such studies have shown the formation of organosulphate species in monoterpene and isoprene SOA, which have also been seen in ambient samples (Iinuma et al., 2007; Liggio and Li, 2006; Surratt et al., 2007). Volkamer et al. (2009), found that the yield of SOA from acetylene photo-oxidation, where the main product is glyoxal, strongly depends on the chemical composition of the seed particles. In this case, use of an ammonium sulphate seed led to one of the lowest SOA yields. However, the yield was significantly increased by the addition of fulvic acid to the ammonium sulphate. Jang et al. (2003) used seed particles from diesel engine exhaust in chamber studies to mimic primary organic aerosol. However, diesel and fulvic acid are made up of thousands of compounds and identifying SOA components arising from a known precursor in such a complex matrix is extremely difficult. In both cases there is a disparity between the chemical properties of the seed and the oxidised organic compounds partitioning to form SOA. In the atmosphere most organic aerosol (OA) is oxidised, even in urban areas (Jimenez et al., 2009; Zhang et al., 2007). Thus, a better seed particle to simulate many environments would be an oxidised organic aerosol (OOA). There are a number of difficulties involved with using OOA as a seed. Firstly, which organic compound is most suitable? Previous studies have used dioctylphthalate (Song et al., 2007) and highly oxidised organic acids (Corrigan et al., 2008) as a surrogate of SOA, but these are single compounds, rather than the range of molecular weights and functionalities seen in the atmosphere. Oxidised compounds are also generally difficult to work with and stick to surfaces.

A more appropriate seed for investigating the partitioning of a wide range of semi-volatile OVOCs would be SOA itself. Dommen et al. (2009) used $\alpha$-pinene SOA as a seed aerosol for isoprene SOA although the isoprene was ${ }^{13} \mathrm{C}$ labelled to allow the seed to be differentiated. This method required the use of plants to fix ${ }^{13} \mathrm{CO}_{2}$, which then emitted labelled isoprene and thus is limited to this particular VOC. Here we present the use of sesquiterpene SOA, formed from $\beta$-caryophyllene photo-oxidation, as a seed particle for simulation chamber experiments. Within this work, $\beta$-caryophyllene SOA seed has been used to study the generation of SOA from limonene photo-oxidation. $\beta$ Caryophyllene reacts rapidly with hydroxyl radicals and ozone resulting in almost immediate nucleation owing to the high molecular weight and low volatility of its first generation oxidation products. The chamber was subsequently diluted to obtain a low particle concentration and remove the majority of the gas phase products. The VOC to be studied, in this case limonene, was then introduced into the chamber and oxidised. The gas phase loss of limonene and the formation of its oxidation products were followed by Chemical Ionisation Reaction Time of Flight Mass Spectrometry (CIRTOF-MS). The partitioning of limonene oxidation products to the seed was followed by monitoring the shift in the particle size distribution. The change in bulk chemical composition was analysed in real time using Aerosol Mass Spectrometry. The difference in the detailed chemical composition between the seed and the limonene SOA was analysed offline using Comprehensive Two-dimensional Gas Chromatography Time-of-Flight Mass Spectrometry $(\mathrm{GC} \times \mathrm{GC}$ TOF/MS), Liquid Chromatography Ion Trap Mass Spectrometry $\left(\mathrm{LC}^{-\mathrm{MS}^{n}}{ }^{n}\right.$ ) and Fourier Transform Ion Cyclotron Resonance Mass Spectrometry (FTICR-MS).

\section{Experimental}

\subsection{Chamber}

A comprehensive and detailed description of the University of Manchester Aerosol Chamber will be presented in a future publication (McFiggans et al., 2011), hence only an introduction and general overview is provided here. The Manchester aerosol chamber is an $18 \mathrm{~m}^{3}(3 \mathrm{~m}(\mathrm{H}) \times 3 \mathrm{~m}(\mathrm{~L}) \mathrm{m}(\mathrm{H}) \times 3 \mathrm{~m}$ $2 \mathrm{~m}(\mathrm{~W}))$ FEP Teflon bag mounted on three rectangular aluminium frames. The central rigid rectangular frame is fixed, with the upper and lower frames free to move vertically causing the bag to expand and collapse as sample air is introduced and extracted. A bank of halogen lamps and a $6 \mathrm{~kW}$ Xenon arc lamp are mounted on the enclosure housing the bag which is coated with reflective "space blanket" serving to render the enclosure as an integrating sphere, maximising the irradiance in the bag and ensuring even illumination. The combination of illumination has been tuned and evaluated to mimic the atmospheric actinic spectrum over the wavelength range $290-800 \mathrm{~nm}$, and has a maximum total actinic flux of $0.7 \times 10^{18}$ photos $\mathrm{s}^{-1} \mathrm{~m}^{-2} \mathrm{~nm}^{-1}$ over the region 460 $500 \mathrm{~nm}$. The calculated $j\left(\mathrm{O}^{1} \mathrm{D}\right)$ value during the reported experiments was $3.6 \times 10^{-5} \mathrm{~s}^{-1}(290-340 \mathrm{~nm})$. Air conditioning between the enclosure and the bag removes additional unwanted heat generated by the lamps. The air charge in the bag is dried and filtered for gaseous impurities and particles using a combination of Purafil (Purafil SP media from Purafil, Inc., USA), charcoal and HEPA filters (Donaldson 
Filtration (GB) Ltd), prior to humidification with ultrapure deionised water. This setup was found to be efficient at removing VOCs, $\mathrm{NO}_{2}$ and $\mathrm{O}_{3}$, but was not fully able to remove NO.

Parent VOCs are introduced into the chamber through injection into a heated glass bulb fed with a flow of filtered nitrogen. $\mathrm{NO}_{\mathrm{x}}$ levels are controlled by injection from a cylinder into the charge line and a high capacity $\mathrm{O}_{3}$ generator was employed to control initial $\mathrm{O}_{3}$ concentrations as well as serving as a cleaning agent during flushing between experiments. Cycling between experiments is facilitated by full computer control as is the monitoring of key chamber conditions (e.g. temperature and relative humidity). Automatic fill/flush cycling to clean the chamber before and after each experiment with $3 \mathrm{~m}^{3} \mathrm{~min}^{-1}$ flow of scrubbed, dried, rehumidified (and optionally ozonised) air is achieved by control of electro-pneumatic valves. Each cycle takes approximately $12 \mathrm{~min}$ and cleaning is normally achieved after 5 or 6 cycles. Coupling morning and evening cycling with overnight soaking at ppm levels of $\mathrm{O}_{3}$, allows experiments to be carried out on subsequent days. Longer experiments are possible on 2-day cycles. Relative humidity (RH) and Temperature (T) are measured at several points throughout the chamber (by dewpoint hygrometer and a series of thermocouples and resistance probes, respectively) and are controlled by diverting air through the inlet humidification circuit and by controlling the air conditioning setpoint respectively.

\subsection{Experimental methodology}

The secondary organic aerosol seed was generated from the photo-oxidation of $\beta$-caryophyllene in the presence of $\mathrm{NO}_{\mathrm{x}}$ (Initial VOC: $\mathrm{NO}_{\mathrm{x}} \sim 1-2$ ) using a conventional nucleation and growth experiment. The experimental details are summarised in Table 1. Approximately $98-99 \%$ of the precursor $\beta$-caryophyllene had reacted after about $3 \mathrm{~h}$. This was verified using the CIR-TOF-MS. After this time, chamber lights were turned off, and a fraction of the chamber content was flushed out and replaced by clean air. This resulted in dilution of the seed concentration down to approximately 4 to $13 \mu \mathrm{g} \mathrm{m}^{-3}$ depending on the experiment and also the dilution of the gas phase reactants. During the dilution phase, limonene was injected into the chamber and, if required, the $\mathrm{NO}_{\mathrm{x}}$ level was adjusted by the injection of an additional quantity of $\mathrm{NO}_{2}$ gas, to keep the VOC: $\mathrm{NO}_{\mathrm{x}}$ ratio at around 2 (a fixed ratio was chosen to reduce system variables pertaining to the presence of $\mathrm{NO}_{\mathrm{x}}$ and hence to enable comparisons to be made between experiments). Following this flush/refill phase, chamber lights were turned back on again to allow for the photooxidation of limonene.

Filters were collected in a specially constructed holder, positioned in the chamber vent line. Aerosol samples were collected onto $47 \mathrm{~mm}$ quartz fibre filters (Whatman) at a flow rate of $3 \mathrm{~m}^{3} \mathrm{~min}^{-1}$. Filters were collected during the dilution stage to obtain a $\beta$-caryophyllene seed sample, which was used as a background for the limonene SOA. Limonene SOA samples were collected at the end of the experiment. After sampling, filters were immediately placed in pre-cleaned glass vials and stored below $-20^{\circ} \mathrm{C}$ until analysis.

Experiments were carried out at an average $T$ of $25.7 \pm 0.7{ }^{\circ} \mathrm{C}$ and nominal relative humidity of $71 \pm 1.6 \%$. Chamber humidity was controlled using vapour from heated ultra pure water (Purelab Ultra System, Elga). Known amounts of $\beta$-caryophyllene $\left(\mathrm{C}_{15} \mathrm{H}_{24}\right.$, Sigma Aldrich) and limonene $\left(\mathrm{C}_{10} \mathrm{H}_{16}\right.$, Fluka $\left.\geq 99.0 \%\right)$ were evaporated from a heated glass bulb and continuously flushed into the chamber using a flow of nitrogen. During each experiment the initial chamber $\mathrm{NO}_{\mathrm{x}}$ concentration was controlled by introducing $\mathrm{NO}_{2}$ gas into the chamber from a cylinder containing $10 \%$ $\mathrm{NO}_{2}$ in nitrogen.

\subsection{Gas phase measurements}

$\mathrm{NO}$ and $\mathrm{NO}_{2}$ mixing ratios were measured using a chemiluminescence detector (Model 42i, Thermo Scientific, MA, USA). Ozone was measured using a UV photometric gas analyser (Model 49C, Thermo Scientific, MA, USA). The gas phase organic compounds within the chamber were measured using Chemical Ionisation Reaction Time-of-Flight Mass Spectrometry (CIR-TOF-MS). This technique has been described in detail elsewhere (Blake et al., 2004; Wyche et al., 2007), hence here it is only described in brief alongside experiment specific details.

The CIR-TOF-MS instrument comprises a bespoke, temperature controlled $\left(40^{\circ} \mathrm{C} \pm 0.5\right)$ radioactive $\left({ }^{241} \mathrm{Am}\right)$ ion source/drift cell assembly, coupled to an orthogonal timeof-flight mass spectrometer equipped with a reflectron array (Kore Technolgy Ltd, Ely, UK). During these experiments, proton transfer reaction ionisation was employed as the chemical ionisation technique, utilising hydronium $\left(\mathrm{H}_{3} \mathrm{O}^{+}\right)$as the primary reagent ion (Lindinger et al., 1993). In this instance, the hydronium ions were generated from a humidified $\mathrm{N}_{2}$ carrier gas (purity $=99.998 \%$ ). Providing certain reaction conditions are met, ion molecule reaction between $\mathrm{H}_{3} \mathrm{O}^{+}$and the organic analyte will yield a protonated product ion $\left(\mathrm{RH}^{+}\right)$and neutral water;

$\mathrm{H}_{3} \mathrm{O}^{+}+\mathrm{R} \longrightarrow \mathrm{RH}^{+}+\mathrm{H}_{2} \mathrm{O}$

Despite being considered a relatively soft ionisation method, the nascent $\mathrm{RH}^{+}$ion may be sufficiently energetic so as to dissociate and produce one or more fragment ions (Blake et al., 2009).

Chamber air containing the analyte was delivered in a continuous stream (approximately $230 \mathrm{sccm}$ ) to the drift cell via a $0.5 \mathrm{~m}$ long, $1 / 4$ " (internal diameter) Teflon sample line, heated to $40( \pm 1)^{\circ} \mathrm{C}$. The centre drift cell was operated at an $\mathrm{E} / \mathrm{N}$ (i.e. electric field/gas number density) ratio of approximately $90 \mathrm{Td}$. An energy ramp was applied at the base of the cell to remove potential water-cluster ions (e.g. $\mathrm{RH}^{+} \mathrm{H}_{2} \mathrm{O}$ ). 
Table 1. Experimental details and SOA yields.

\begin{tabular}{|c|c|c|c|c|c|c|c|c|c|c|c|}
\hline $\begin{array}{l}\text { Experiment } \\
\text { Date }\end{array}$ & $\begin{array}{c}\text { Phase } 1 \\
{\left[\mathrm{VOC}_{\beta-c}\right]_{0}{ }^{\mathrm{a}}} \\
/ \mathrm{ppbV}\end{array}$ & $\begin{array}{c}\text { Phase } 2 \\
{\left[\mathrm{VOC}_{\mathrm{lim}}\right]_{0}^{\mathrm{a}}} \\
\text { /ppbV }\end{array}$ & $\begin{array}{c}\Delta\left[\mathrm{VOC}_{\beta-c}\right] \\
/ \mathrm{ppbV}\end{array}$ & $\begin{array}{l}\Delta\left[\mathrm{VOC}_{\lim }\right] \\
\quad / \mathrm{ppbV}\end{array}$ & $\begin{array}{c}\text { Phase } 1 \\
\text { VOC/NO }_{x}{ }^{a}\end{array}$ & $\begin{array}{c}\text { Phase } 3 \\
\text { VOC/NO }_{x}{ }^{a}\end{array}$ & $\begin{array}{l}\text { Phase } 1 \\
\text { Peak Seed } \\
\text { SOA mass } \\
\text { / }^{\mathrm{bgm}}{ }^{-3}\end{array}$ & $\begin{array}{l}\text { Phase } 3 \\
\text { Peak } \\
\text { Measured } \\
\text { SOA mass } \\
\text { / }^{\mathrm{c}} \mathrm{gm}^{-3}\end{array}$ & $\begin{array}{l}\text { Phase } 3 \\
\text { Peak } \\
\text { Condensed } \\
\text { SOA mass }{ }^{\mathrm{d}} \\
/ \mu \mathrm{gm}^{-3}\end{array}$ & $\begin{array}{c}Y_{\mathrm{SOA}} \\
\text { Phase 1 } \\
\text { (Seed) } \\
1 \%\end{array}$ & $\begin{array}{c}Y_{\mathrm{SOA}} \text { Phase } 3 \\
\left(_{\text {(Condensation) }}{ }^{\mathrm{e}}\right. \\
1 \%\end{array}$ \\
\hline 25 Jun 2008 & $\begin{array}{r}48.77 \\
( \pm 8.71)\end{array}$ & $\begin{array}{r}92.82 \\
( \pm 10.19)\end{array}$ & 44.80 & 85.39 & 1.42 & 2.00 & 35.58 & 69.60 & 65.33 & 9.52 & 13.75 \\
\hline 26 Jun 2008 & $\begin{array}{r}52.35 \\
( \pm 9.26)\end{array}$ & $\begin{array}{r}20.83 \\
( \pm 3.58)\end{array}$ & 40.78 & 20.24 & 1.88 & 1.31 & 53.21 & 13.46 & 6.93 & 15.64 & 6.15 \\
\hline $10 \mathrm{Jul} 2008$ & $\begin{array}{r}48.10 \\
( \pm 8.60)\end{array}$ & $\begin{array}{r}52.61 \\
( \pm 6.69)\end{array}$ & 41.84 & 48.39 & 0.64 & 1.88 & 65.80 & 44.76 & 31.28 & 18.86 & 11.62 \\
\hline
\end{tabular}

${ }^{\mathrm{a}}[\mathrm{VOC}]_{0}$ and $\mathrm{VOC} / \mathrm{NO}_{\mathrm{x}}$ based on 5 min integrated CIR-TOF-MS and $\mathrm{NO}_{\mathrm{x}}$ data, ${ }^{\mathrm{b}}$ Maximum measured SOA mass during Phase 1 of the experiment, ${ }^{\mathrm{c}}$ Maximum measured SOA mass during Phase 3 of the experiment, ${ }^{\mathrm{d}}$ Maximum SOA formed from condensation during Phase $3,{ }^{\mathrm{e}}$ SOA yield from condensation during Phase 3.

The CIR-TOF-MS was calibrated via three separate methods: (i) using step-wise dilution of a gravimetrically prepared gas standard (BOC Special Gases, UK) containing a variety of VOCs and oxygenated $(\mathrm{O}) \mathrm{VOCs}$; (ii) using calibration material produced in-house via the injection of liquid samples (prepared by volumetric dilution of the pure material in hexane) into 101 Tedlar bags (SKC Inc., USA) containing both humidified and dry, pure nitrogen; and (iii) using gaseous standards derived from permeation tubes (Vici Inc., US; Eco-scientific, UK), diluted, humidified and delivered to the CIR-TOF-MS by a commercial calibration unit (Kintec, model: 491).

\subsection{Aerosol characterisation}

The total SOA particle number concentration was measured using an ultrafine water-based condensation particle counter (wCPC 3786, TSI, Inc.). This model has a minimum size cut-off of $2.5 \mathrm{~nm}$. The size distribution of the generated SOA particles was measured using a Differential Mobility Particle Sizer (DMPS). The DMPS instrument consists of two Vienna design Differential Mobility Analysers (DMAs) (Williams, 1999): an ultrafine DMA for particles in the size range $3.4-34 \mathrm{~nm}$ and a standard DMA for particle sizes from $20-500 \mathrm{~nm}$. After transmission through the DMAs, particles are counted using condensation particle counters (CPC). The ultrafine DMA was attached to a TSI 3025A CPC and the standard DMA to a TSI 3010 CPC. The DMAs were operated in parallel and utilised a custom built sealed, recirculating sheath air system, which was dried and filtered. Particle size distributions in the diameter size range from $3 \mathrm{~nm}$ to $500 \mathrm{~nm}$ were obtained every $10 \mathrm{~min}$.

A hygroscopicity tandem differential mobility analyser (HTDMA) was used to measure on-line size resolved water uptake at $90 \% \mathrm{RH}$. The HTDMA dries the sample aerosol to $<10 \%$ RH using a Nafion ${ }^{\circledR}$ drier (Perma Pure, MD-110-12, Toms River, NJ, USA). A Strontium-90 aerosol neutraliser then brings the sample into charge equilibrium. A DMA (BMI, Haywood, CA, USA) operated with a re-circulating sheath flow of $51 \mathrm{~min}^{-1}$ and sample flow of $0.51 \mathrm{~min}^{-1}$ selects particles of a single mobility. Diameters chosen were larger than the mode of the number size distribution, thus avoiding the sampling of a significant fraction of multicharged particles. The sample is then humidified to $90 \% \mathrm{RH}$ using a Gore-Tex® humidifier Cubison et al., 2006). The humidified size selected sample is then passed through a residence coil for $15 \mathrm{~s}$. A second DMA (BMI) and CPC (TSI, 3782 ) is then used to measure the size distribution of the humidified sample using the DMPS technique. The temperature of the DMAs and humidification system is controlled using peltier units (Supercool ${ }^{\circledR}$, AA-040-12-22, Sweden). The humidity is measured using a dew point hygrometer (EdgeTech, Dewmaster, MA, USA). The operation of the HTDMA was validated by sampling ammonium sulphate and sodium chloride test aerosols using the operating procedures described by Good et al. (2010) . The data was inverted using the method described by Gysel et al. (2009). The data from the HTDMA is reported in terms of the hygroscopic $\left(\mathrm{GF}_{D_{0}, \mathrm{RH}}\right)$, the wet particle diameter at a given RH divided by the particle's dry diameter $\left(D_{0}\right)$. The aerosol particles measured appeared internally mixed, hence the reported growth factors are the number weighted means of the measured growth factor probability density distributions unless otherwise stated (Gysel et al., 2009).

Measurements of the secondary organic aerosol composition were made using a compact Time-of-flight Aerosol Mass Spectrometer (Drewnick et al., 2005) (cToF-AMS, Aerodyne Research Inc., USA). The instrument operated in the standard configuration, taking both mass spectrum (MS) and particle time-of-flight (pToF) data, and was calibrated using $350 \mathrm{~nm}$ monodisperse ammonium nitrate particles. A more detailed description of the instrument and its calibration was provided by Drewnick et al. (2005).

The detailed chemical composition of the SOA was determined from filter samples using two complementary techniques. The semi-volatile fraction of the SOA was analysed using direct thermal desorption coupled to $\mathrm{GC} \times \mathrm{GC}$ TOF/MS. A small piece of the filter (weight between 
10-20 mg) was cut out, placed inside a thermal desorption glass vial and injected using an autosampler. Two stage thermal desorption was used to ensure a narrow band of analytes was injected onto the column (MPS2 autosampler and TDU/CIS4, Gerstel, Germany). GC $\times$ GCTOF/MS was carried out using a cryo-jet Pegasus 4D (Leco, St. Joseph, MI, USA) incorporating an Agilent 6890N Gas Chromatograph and a Pegasus III reflectron time-of-flight mass spectrometer. A liquid nitrogen cooled gas jet midpoint modulator, at approximately $-160{ }^{\circ} \mathrm{C}$, was used to enable comprehensive two-dimensional separations. A secondary oven housed within the GC oven allowed independent column temperature control. The column set used in these experiments provides a primary volatility based separation followed by a secondary polarity based separation. The first dimension was a $5 \%$ phenyl- $95 \%$ methylpolysiloxane $30 \mathrm{~m} \times 320 \mu \mathrm{m} \times 1.0 \mu \mathrm{m}$ HP-5 (J\&W Scientific, Wilmington, DE, USA). The second column was a $50 \%$ phenyl-polysiloxane $2 \mathrm{~m} \times 100 \mu \mathrm{m} \times 0.1 \mu \mathrm{m}$ BP10 (SGE, Melbourne, Australia). The GC was held at $70^{\circ} \mathrm{C}$ for two minutes and then raised at $2.5^{\circ} \mathrm{C} \mathrm{min}^{-1}$ to $250{ }^{\circ} \mathrm{C}$ and held at this temperature for a further sixteen minutes. The carrier gas was helium (99.9999\%, BOC Gases, Guildford, UK) supplied at $1.5 \mathrm{ml} \mathrm{min}^{-1}$. The modulator and secondary oven were operated at $+30^{\circ} \mathrm{C}$ and $+15^{\circ} \mathrm{C}$ above GC oven temperature respectively.

The remainder of the filter sample was extracted into high purity water, filtered and reduced to $1 \mathrm{ml}$ using a vacuum solvent evaporator (Biotage, Sweden). The water soluble and high molecular weight compounds were analysed using liquid chromatography-ion trap mass spectrometry $\left(\right.$ LC-MS ${ }^{n}$ ). LC-MS was carried out using an HCT Plus ion trap mass spectrometer (Bruker Daltonics GmbH, Bremen, Germany) equipped with an Eclipse ODS- $\mathrm{C}_{18}$ column with $5 \mu \mathrm{m}$ particle size (Agilent, $4.6 \mathrm{~mm} \times 150 \mathrm{~mm}$ ). Both positive and negative ionisation modes were used. Full details of the methodology and instrument have been published previously (Hamilton et al., 2008).

Samples were also analysed at high resolution using a Bruker APEX 9.4 T Fourier Transform Ion Cyclotron Resonance Mass Spectrometer. Extracts were sprayed at a flow rate of $2 \mu \mathrm{L} \mathrm{min}^{-1}$, into an Apollo II electrospray interface with ion funnelling technology. Spectra were acquired in both positive and negative ion mode over the scan range $\mathrm{m} / \mathrm{z}, 100-3000$ using the following MS parameters: nebulising gas flow: $0.91 \mathrm{~min}^{-1}$, drying gas flow: $51 \mathrm{~min}^{-1}$, drying temperature: $190^{\circ} \mathrm{C}$, collision cell accumulation: $0.05-$ $0.5 \mathrm{~s}$, and data acquisition size: $2 \mathrm{MB}$ (yielding a target resolution of 130000 at $\mathrm{m} / \mathrm{z}, 400$ ). Data were analysed using DataAnalysis 4.0 software (Bruker Daltonics, Bremen, Germany). The instrument was calibrated using protonated (positive ion mode) or deprotonated (negative ion mode) arginine clusters. The mass spectra were internally recalibrated with a series of prominent peaks: positive $-\mathrm{C}_{10} \mathrm{H}_{16} \mathrm{NaO}_{3}$, $\mathrm{C}_{12} \mathrm{H}_{20} \mathrm{NaO}_{3}, \mathrm{C}_{13} \mathrm{H}_{22} \mathrm{NaO}_{3}, \mathrm{C}_{14} \mathrm{H}_{22} \mathrm{NaO}_{3}, \mathrm{C}_{14} \mathrm{H}_{22} \mathrm{NaO}_{4}$,
$\mathrm{C}_{16} \mathrm{H}_{28} \mathrm{NaO}_{4}$; negative $-\mathrm{C}_{10} \mathrm{H}_{15} \mathrm{O}_{5}, \mathrm{C}_{9} \mathrm{H}_{14} \mathrm{O}_{4}, \mathrm{C}_{10} \mathrm{H}_{15} \mathrm{O}_{4}$, $\mathrm{C}_{10} \mathrm{H}_{16} \mathrm{O}_{5}, \mathrm{C}_{14} \mathrm{H}_{22} \mathrm{O}_{4}$. Background contaminants also seen in pure water and blank extracted filters were removed and intensity weighted $\mathrm{O}: \mathrm{C}$ and $\mathrm{H}: \mathrm{C}$ ratios were calculated. Three dimensional Van Krevelen plots were created in IDL v6.3 (ITTVIS), with data displayed in contour plots over 10 contour levels. Data were interpolated between sample points and the intensity scaled to $70 \%$ of the maximum value.

\section{Results and discussion}

The experimental details are given in Table 1. A typical experiment is split into three phases:

- In phase 1 , the $\beta$-caryophyllene was introduced, the lights turned on and SOA formed.

- In phase 2, the lights were turned off, the chamber was flushed to reduce seed and VOC concentrations, then diluted with clean air while the limonene was injected into the chamber.

- In phase 3, the lights were turned on and limonene photo-oxidation occurred followed by product condensation onto the organic seed.

The evolution of certain key parameters is shown in Fig. 1 for a typical example of the organic seed experiments (25 June 2008). In Fig. 1, the beginning of phase 1 occurs at time $=0$ and the vertical red dotted lines show the beginning and end of phase 2 . In this experiment $49( \pm 9) \mathrm{ppbV}$ of $\beta$-caryophyllene was introduced into the chamber along with sufficient $\mathrm{NO}_{2}$ gas to give an initial $\mathrm{NO}_{\mathrm{x}}$ (i.e. the sum of $\mathrm{NO}$ and $\left.\mathrm{NO}_{2}\right)$ concentration of $34( \pm 1)$ ppbV. This VOC and $\mathrm{NO}_{\mathrm{x}}$ combination thus gave an initial $\mathrm{VOC} / \mathrm{NO}_{\mathrm{x}}$ ratio of approximately 1.4. It should be noted that no additional NO gas was added to the chamber matrix at any time and the initial quantity of NO observed in Fig. 1 at the beginning of each experiment phase, results from incomplete scrubbing of the charge gas for NO. Following injection of the reactants the chamber lights were turned on (at time $=0$ ) and almost immediately the SOA mass in the chamber was observed to increase. The SOA number density peaked after $10 \mathrm{~min}$ and the mass concentration peaked at around $36 \mu \mathrm{g} \mathrm{m}^{-3}$ after $60 \mathrm{~min}$. A density of 1.3 was used for both the $\beta$-caryophyllene and limonene SOA based on the most recent literature to calculate the SOA mass from the DMPS volume data (Bahreini et al., 2005; Varutbangkul et al., 2006). Very little ozone was observed to accumulate within the chamber during phase 1 , (maximum of $8( \pm 2) \mathrm{ppbV}$ at the end of phase 1 owing to its rapid reaction with the $\beta$-caryophyllene (lifetime of $\beta$-caryophyllene with $30 \mathrm{ppbV} \mathrm{O}_{3}$ is around $2 \mathrm{~min}$ ). In comparison with other VOC chamber photo-oxidation systems (Odum et al., 1997), $\beta$-caryophyllene chamber photooxidation results in relatively unusual $\mathrm{NO}_{\mathrm{x}}$ chemistry, which 

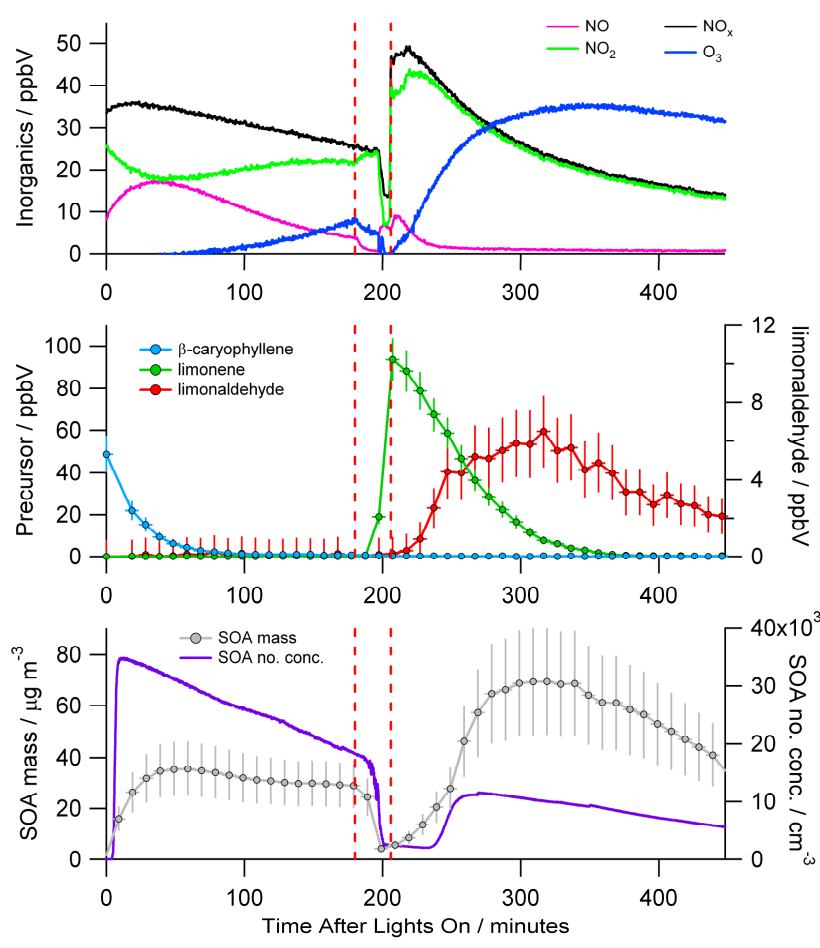

Fig. 1. Evolution of basic chamber measurements during 25 June 2008 experiment.

will be discussed in more detail in a future publication (Alfarra et al., 2011). In brief however, the $\mathrm{NO}_{\mathrm{x}}$ behaviour observed in Fig. 1 may be a result of the fast reaction rate of $\beta$-caryophyllene with ozone and resultant low radical yields.

Following near complete reaction of the $\beta$-caryophyllene (98-99\% oxidation), the chamber was then diluted to leave a $\beta$-caryophyllene organic seed aerosol background of approximately $4 \mu \mathrm{g} \mathrm{m}^{-3}$. No change in particle size (due to revolatilisation) was seen during dilution, indicating that the $\beta$-caryophyllene SOA was mostly composed of low volatility compounds. Figure 2 shows a comparison of SOA size distributions measured immediately before the lights were turned off at the end of phase 1 (before dilution) and the immediately before lights were turned back on at the start of phase 3 (after dilution). Grieshop et al. (2007) showed that SOA from $\alpha$-pinene ozonolysis repartitions reversibly upon dilution, but on a much longer time scale than has been observed in single component aerosols of similar sizes. Our dilution time scale was much shorter and did not lead to any volatilisation of SOA. It should be noted however, that volatilisation of some of the SOA material may occur over longer time scales but this was not explored here. During phase 2, ozone levels in the chamber dropped below the detection limit of the instrument $(2 \mathrm{ppbV})$, indicating that the ozone mixing ratio was near zero before the start of phase 3. Following dilution, 93 $( \pm 10) \mathrm{ppbV}$ of limonene was injected into the chamber before an additional "top-up" injection of $\mathrm{NO}_{\mathrm{x}}$ was added (in

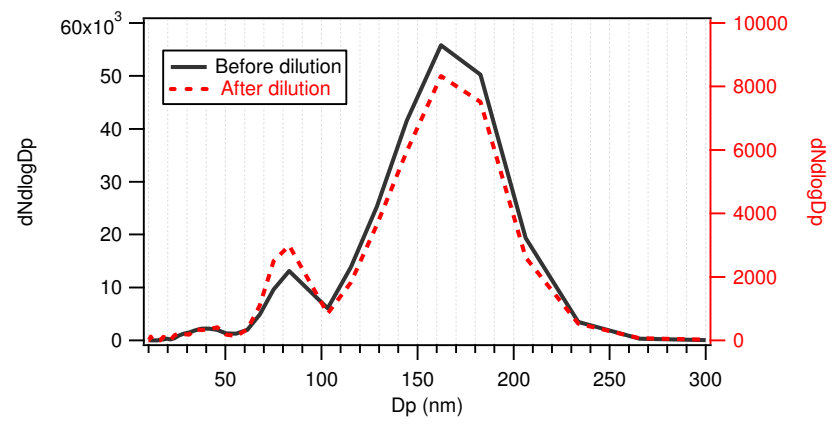

Fig. 2. Particle size distribution of the $\beta$-caryophyllene seed particles. Black line indicates size distribution at the end of Phase 1 (predilution). Red line indicates size distribution at the end of Phase 2 (after flushing and dilution).

the form of $\mathrm{NO}_{2}$ ) to ensure an initial $\mathrm{VOC} / \mathrm{NO}_{\mathrm{x}}$ ratio similar to that of phase 1 (i.e. $\sim 2.0$ ). On average for the three experiments, less than $0.5( \pm 1) \mathrm{ppbV}$ of $\beta$-caryophyllene remained in the chamber following dilution. Also, from the application of a pseudo calibration sensitivity to the data (obtained for the $\mathrm{C}_{10}$ multifunctional monoterpene oxidation product, pinonaldehyde), it is estimated that an average of only 2-3 $( \pm 1) \mathrm{ppbV}$ of $\beta$-caryophyllene oxidation products were carried over to phase 3 of the experiment. In addition, complete evaporation of the seed particle post-dilution could only have contributed to a maximum of $0.5 \mathrm{ppbV}$ of the caryophyllenic VOC observed; in practice this would be very much lower.

Limonene oxidation was observed by the CIR-TOF-MS during phase 3 of the experiment, after chamber lights had been switched back on. For all experiments limonene was quantified from the spectral signal corresponding to the protonated limonene parent ion $(\mathrm{m} / \mathrm{z}$ 137). During phase 3 , the decay of limonene was matched by the concomitant production of its gas phase reaction products, including limonaldehyde $(\mathrm{m} / \mathrm{z} 169,151$ and 107) and limonaketone $(\mathrm{m} / \mathrm{z}, 139)$. The oxidation of limonene and the production of limonaldehyde are shown in Fig. 1. Limonene oxidation and limonaldehyde formation was reproducible between experiments, with approximately all of the limonene reacted by the end of phase 3 (i.e. after $240 \mathrm{~min}$ ) in each instance and limonaldehyde formed in molar yields of $\sim 7-14 \%$. The formation of ozone and more conventional chamber $\mathrm{NO}_{\mathrm{x}}$ chemistry observed during phase 3 can also be seen in Fig. 1, with a maximum of $35( \pm 2)$ ppb of ozone produced. The SOA mass (as well as seed particle size) increased steadily from lights on until $240 \mathrm{~min}$, where a second nucleation event was seen, with a steep jump in the particle number concentrations. This can be seen in the particle size distribution shown in Fig. 3.

It is clear from Fig. 1 that limonene oxidation products are partitioning onto the organic seed aerosol increasing aerosol mass from $4 \mu \mathrm{g} \mathrm{m}^{-3}$ to $70 \mu \mathrm{g} \mathrm{m}^{-3}$, giving an average mass growth of $34.5 \mu \mathrm{g} \mathrm{m}^{-3} \mathrm{~h}^{-1}$. The particles grew from 150 to $325 \mathrm{~nm}$ mean diameter during the first 50 min after lights on 


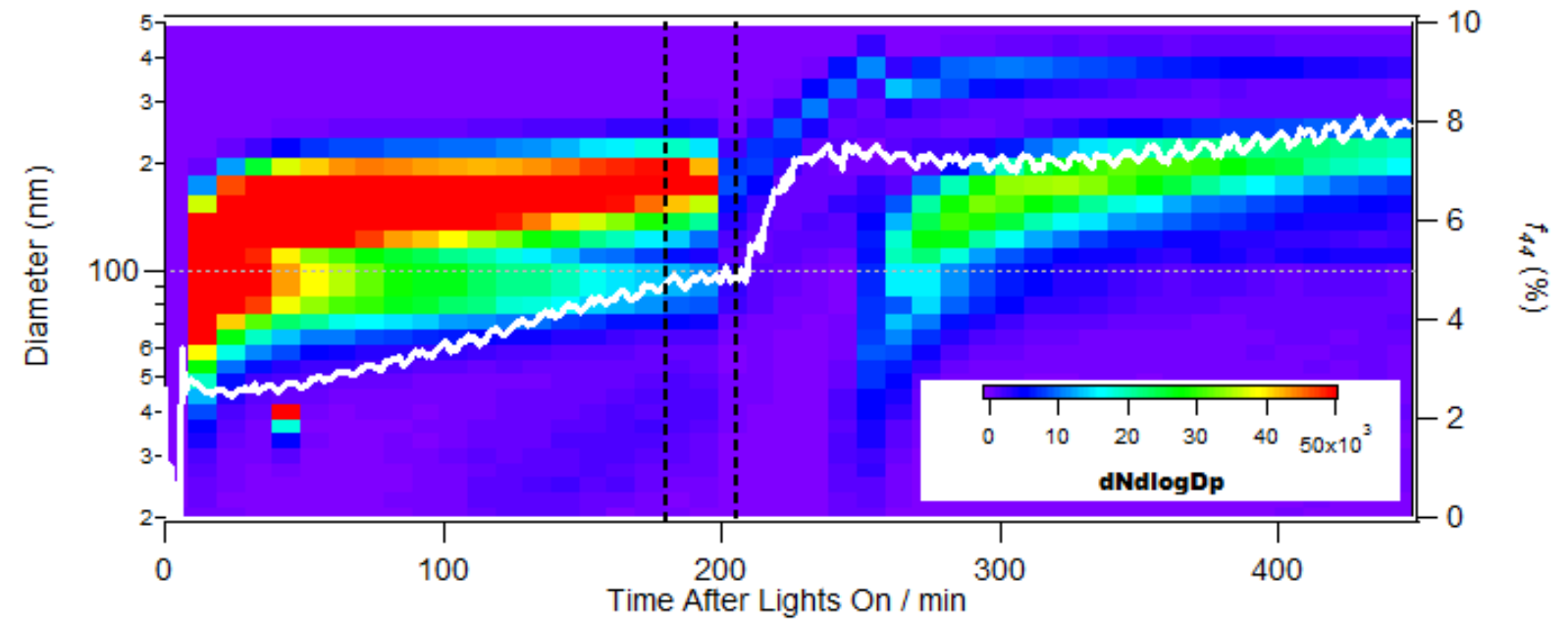

Fig. 3. Particle size distribution during 25 June 2008 experiment and $f_{44}(\%)$ from the AMS measurements.

in phase 3, as shown in Fig. 3, giving an average size growth of $3.5 \mathrm{~nm} \mathrm{~min}^{-1}$. The formation of small particles in the second nucleation event effectively reduces further uptake onto the seed particles. In order to suppress the limonene nucleation, a series of experiments was carried out under different conditions, including reducing the amount of limonene to 21 $( \pm 4) \mathrm{ppb}$ in one experiment and increasing the amount of organic seed to $13 \mathrm{\mu g} \mathrm{m}^{-3}$ in another. In all cases, limonene nucleation could not be suppressed. Potential reasons for this may include the following; (i) there is insufficient particle mass onto which the limonene oxidation products can absorb, (ii) the loss of such limonene oxidation products to seed surface area is slower than the production of condensable material, meaning the partial pressure increases sufficiently high to exceed the nucleation threshold, (iii) the $n$-th generation oxidation product is so condensable that its partial pressure increases to relatively low values, which are above the nucleation threshold and iv) one or more of the limonene OVOCs are not fully miscible in the $\beta$-caryophyllene SOA products such that they would prefer to be in the gas phase until they build up to concentrations above the nucleation threshold. To allow comparison of limonene SOA composition formed from nucleation only and from an organic seeded experiment, the experiment could be stopped immediately as new particle formation was observed and a filter was collected. This would minimise the mass of limonene nucleation SOA collected in seeded experiments and will be carried out in future studies.

$\beta$-caryophyllene photo-oxidation during phase 1 of the organic seed experiments resulted in the production of a peak SOA mass of the order $36-66 \mu \mathrm{g} \mathrm{m}^{-3}$, between 40 and $60 \mathrm{~min}$ after initial lights on (see Table 1). Substituting these masses into Eq. (2), along with the fraction of $\beta$ caryophyllene reacted, allows the SOA yield $\left(Y_{\mathrm{SOA}}\right)$ to be determined:
$Y_{\mathrm{SOA}}=\frac{M_{p}}{\Delta \mathrm{VOC}}$

For phase 1 of the seed experiments, $Y_{\mathrm{SOA}}$ was determined to be of the order 10-19\%. During phase 3 of the experiments, the condensation of limonene photo-oxidation products onto the $\beta$-caryophyllene seed resulted in the production of an additional $7-65 \mu \mathrm{g} \mathrm{m}^{-3}$ of SOA mass on top of the seed, such that the peak mass was measured to be $13-70 \mu \mathrm{g} \mathrm{m}^{-3}$ between 110 and $135 \mathrm{~min}$ after second lights on, giving $Y_{\mathrm{SOA}}$ for the condensed mass of the order 6-14\%. Owing to the lack of appropriate data, these mass and yield values have not been wall loss corrected. Recent work has shown that wall loses of SVOCs may be significant in chamber studies (Matsunaga and Ziemann, 2010), which could lead to an additional factor of uncertainty in the yield values quoted here. However, high molecular weight and low volatility oxidation products (such as those derived from $\beta$-caryophyllene and limonene) are believed to partition quickly to the aerosol phase and hence their gas phase concentrations will be less influenced by the presence of chamber walls. As the measured SOA mass loading of the chamber does not account for loss of particle mass to the chamber walls, the yields presented here are expected to constitute a lower limit for these experiments.

The hygroscopic growth at $90 \% \mathrm{RH}$ was measured by the HTDMA. In order to measure the effect of partitioning to the seed, a series of nucleation only experiments were carried out for both $\beta$-caryophyllene and limonene. These single precursor experiments were for nominal mixing ratios of $50 \mathrm{ppbV}$ and $250 \mathrm{ppbV}$ and selected dry particle diameters between $50 \mathrm{~nm}$ and $500 \mathrm{~nm}$. The growth factor of the pure $\beta$-caryophyllene SOA ranged from 1.00 to 1.06 in the 5 th to 95 th percentile range when binned at $60 \mathrm{~min}$ intervals from 30 min after lights on (illustrated in Fig. 4's upper panel) over 8 separate experiments. Ageing resulted in a small increase in the growth factor over $270 \mathrm{~min}$. The growth factor of the 

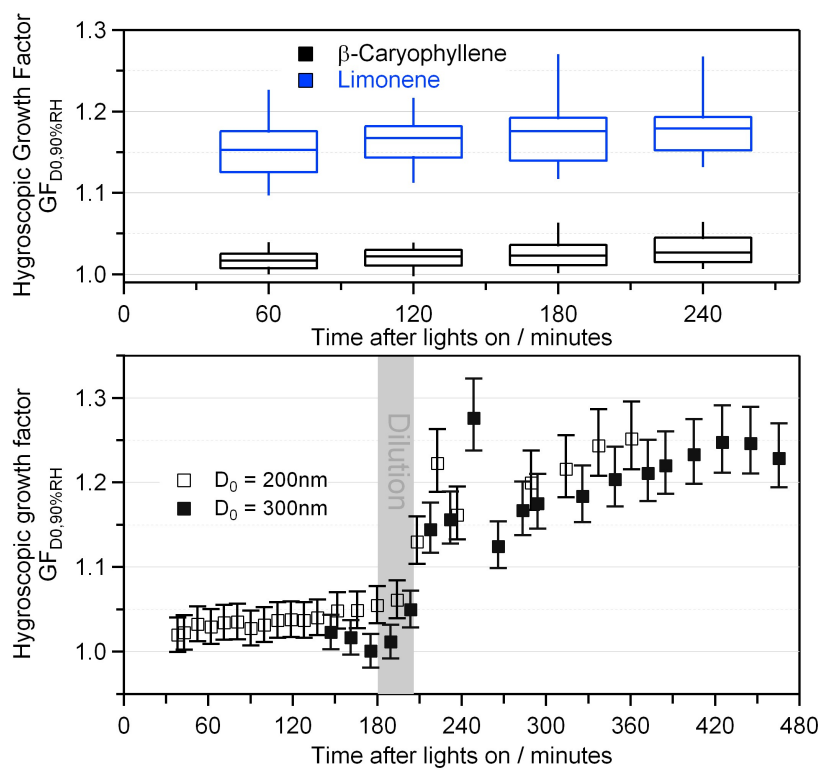

Fig. 4. Hygroscopic growth factor measurements at $90 \%$ RH. The upper panel shows the growth factors of un-seeded limonene and $\beta$-caryophyllene experiments. The data is averaged over $60 \mathrm{~min}$ intervals, box (25th and 75th percentile) and whisker (5th and 95th percentile) plots show the range of pure precursor growth factors measured. The lower panel shows the evolution of the growth factor with time of the $\beta$-caryophyllene seed aerosol which is diluted (after $180 \mathrm{~min}$ ) to act as seed for the subsequent limonene injection (at $205 \mathrm{~min}$ ).

pure limonene SOA ranged from 1.11 to 1.27 (also binned at $60 \mathrm{~min}$ intervals) in the 5th to 95th percentile range (illustrated in Fig. 4's upper panel) over 6 experiments, with an increase mainly within the first $120 \mathrm{~min}$ due to ageing. The lower panel in Fig. 4 shows the growth factor measured during the 25 June 2008 limonene on $\beta$-caryophyllene seed experiment. When the $\beta$-caryophyllene aerosol was diluted for use as a seed its hygroscopic growth did not change significantly from its undiluted behaviour. After the limonene injection and lights on, condensation of limonene oxidation products on to the seed results in a rapid increase in the growth factor. Several hours after the limonene injection the growth factors were comparable to those measured in the limonene nucleation experiments.

The bulk composition of the $\beta$-caryophyllene seed was investigated using a c-ToF-AMS. The relative abundance of the ion signal $\mathrm{m} / \mathrm{z}, 44$ expressed as a fraction of total organic signal $\left(f_{44}\right)$ has been widely used as a proxy for the level of oxygenation of organic aerosols (Alfarra et al., 2004, 2006; Zhang et al., 2007). Mass fragment 44 is due mostly to the ion fragment $\mathrm{CO}_{2}^{+}$, and has previously been shown to strongly correlate with organic $\mathrm{O}: \mathrm{C}$ for ambient and chamber OA (Aiken et al., 2008). For the $\beta$-caryophyllene seed, $f_{44}$ was found to be $4.6 \%$ at the end of phase 1 , indicating a low degree of oxidation, as expected if first generation products are nucleating to form the seed within $5 \mathrm{~min}$ of lights on (see Fig. 3). Compositional analysis indicated that the main $\beta$-caryophyllene oxidation species in the seed were $\beta$-caryophyllonic acid and $\beta$-caryophyllinic acid, which are first generation products. This finding is in agreement with the work or Jaoui et al. (2003, 2007), who reported the first measurements of $\beta$-caryophyllinic acid in SOA generated from the photo-oxidation of $\beta$-caryophyllene, but is in slight contrast to the recent work of Li et al. (2011), who reported the presence of several other compounds amongst the most abundant species in their $\beta$-caryophyllene SOA, formed from the dark ozonolysis of $\beta$-caryophyllene. Besides $\beta$-caryophyllinic acid (and its structural isomers), the most abundant species observed by $\mathrm{Li}$ et al. (2011) included: 3-(4-acetyl-7,7-dimethyl-3-oxabicyclo[4.2.0]oct4-en-2-yl) propanoic acid, 2,3-dihydroxy-4-[2-(4-hydroxy3-oxobutyl)-3,3-dimethylcyclobutyl]-4-oxobutanoic acid and 4-[3,3-dimethyl-2-(3-oxobutyl) cyclobutyl]-3-hydroxy4-oxobutanoic acid (and structural isomers). Furthermore, $\mathrm{Li}$ et al. (2011) state that these latter three compounds, amongst the most abundant components of their SOA, constitute second-generation species. When limonene oxidation products condense onto the seed in phase $3, f_{44}$ increases rapidly to $7.4 \%$, showing that limonene SOA is much more oxidised than the seed. It can be seen in Fig. 3 that the seed ages slowly with a steady increase in $f_{44}$ during phase 1 to a final value of around $5 \%$ after $3 \mathrm{~h}$. The addition of limonene SOA resulted in a much steeper jump in the degree of oxidation of the aerosol, confirming this increase is not due to seed processing.

The detailed composition of the seed and the limonene $\mathrm{SOA}+$ seed were investigated using two offline techniques, $\mathrm{GC} \times \mathrm{GC}-\mathrm{TOF} / \mathrm{MS}$ and $\mathrm{LC}-\mathrm{MS}^{n} . \mathrm{GC} \times \mathrm{GC}$ has been successfully used to study chamber generated SOA for a range of precursors (Hamilton et al., 2005, 2010). The GC $\times$ GC chromatograms obtained by thermal desorption of both seed and limonene filter samples are shown in Fig. 5, where the $\mathrm{x}$ - and $\mathrm{y}$-axis represents retention time on column 1 and 2 respectively and response is indicated by a coloured contour. The chromatograms shown are total ion chromatograms. In the $\mathrm{GC} \times \mathrm{GC}$ set up used, increasing retention time on column 1 indicates decreasing volatility and increasing retention time on column 2 indicates increasing polarity. The $\beta$-caryophyllene seed chromatogram in Fig. 5a, has a complex composition, with the highest concentration of spots circled in yellow. The position of the seed spots on the contour plot indicates that this is low volatility and low polarity material. MS fragmentation patterns can be used to identify a small number of components, but there are very few appropriate EI spectra available for comparison. As shown in Fig. 5, there is a clear difference between the chromatogram of the $\beta$-caryophyllene seed and the limonene SOA + seed sample, with an increased number of species present in the latter. The majority of the limonene SOA, shown within the pink circle of Fig. 5b, has a lower retention time on column 

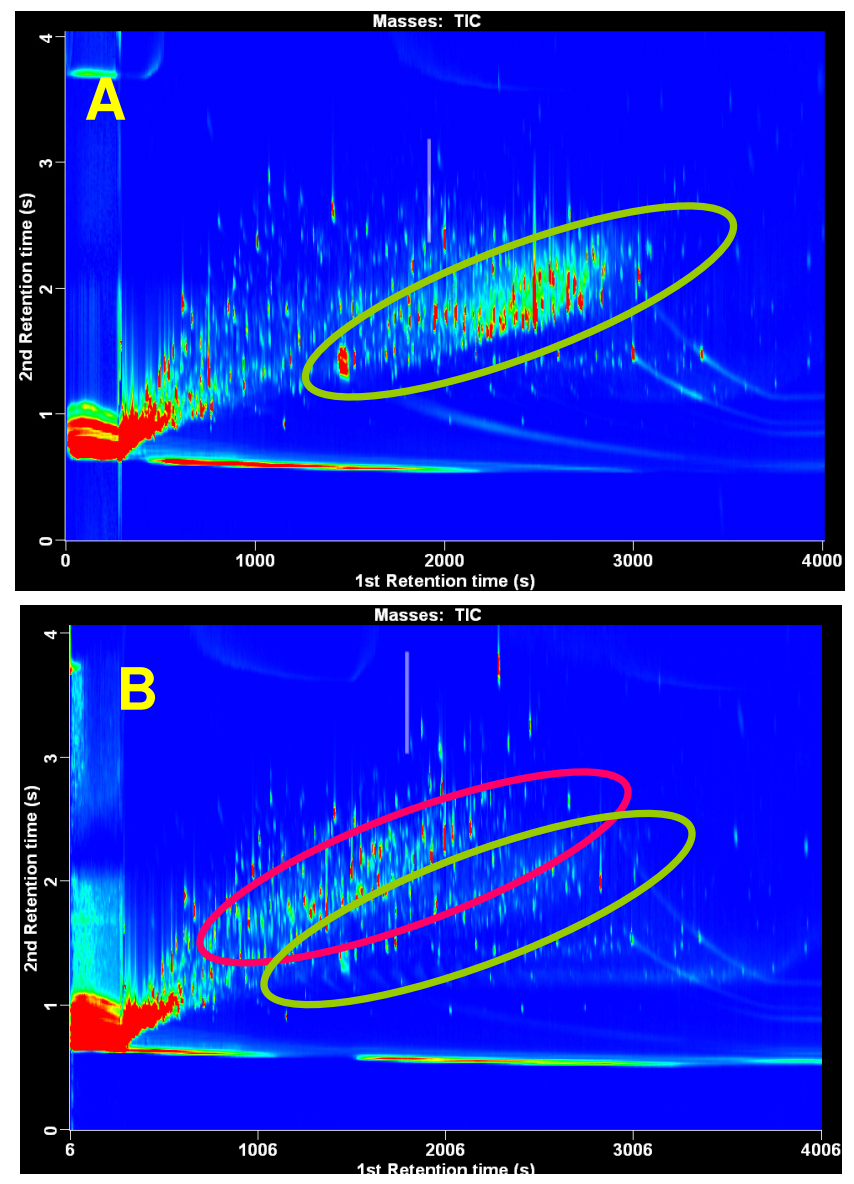

Fig. 5. $\mathrm{GC} \times \mathrm{GC}$ total ion contour plots $-(\mathbf{A})$ : $\beta$-caryophyllene seed. (B): Limonene SOA + seed. Yellow circle indicates highest concentration of seed compounds. Pink circle indicates limonene SOA compounds.

1 and an increased retention time on column 2, indicating that it is more volatile and more polar than the seed, respectively. This qualitatively correlates well with the increase in $f_{44}$ seen in the AMS spectra. $\beta$-caryophyllene is therefore a useful material to use as the seed for studying monoterpene SOA owing to its higher molecular weight, which allows a clear distinction from the condensing organics. The high polar resolving power of $\mathrm{GC} \times \mathrm{GC}$ has a clear advantage for these samples over conventional GC-MS. However, the desorption temperature of the $\mathrm{GC}$ technique $\left(350^{\circ} \mathrm{C}\right)$ may be insufficient to volatilise the least volatile $\beta$-caryophyllene SOA components (based on vapour pressure estimates of known species and those identified by FTICR-MS in this study) and thus a complementary technique is required.

LC-MS has also been used to investigate the composition of the water soluble extracts of the two samples. Positive ionisation, where all peaks exist as their $[\mathrm{M}+\mathrm{Na}]^{+}$adducts, was used to provide a response for the widest range of functionalities. All mass spectra across the entire LC retention time were averaged (reducing artefact formation from direct

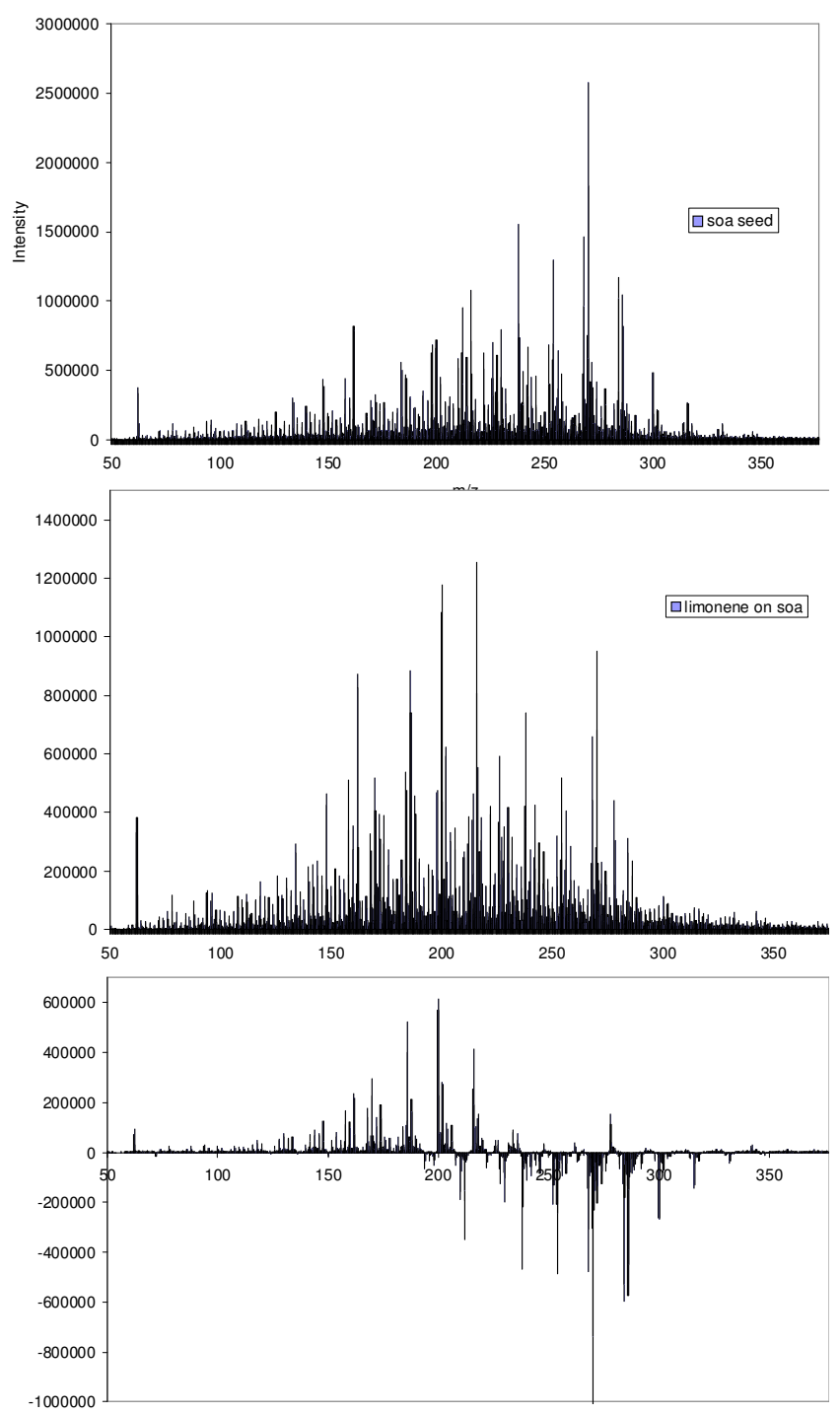

Fig. 6. Average mass spectrum of filter extracts. Upper: $\beta$ caryophyllene seed. Middle: limonene SOA + seed. Lower: Difference mass spectra.

ESI analysis) to obtain a molecular weight distribution representing the seed and the limonene SOA + seed and these are shown in Fig. 6 . The $m / z$ axis has been shifted by $23 \mathrm{Da}$ to give the molecular weight rather than the adduct ion mass. Using this sytem, sodium attaches itself to nearly every oxygenated molecule. This is true for standard mixtures and previous SOA samples. This is confirmed by the FTICRMS, where $>95 \%$ of molecular formulae identified in positive mode contain a Na ion. The $\beta$-caryophyllene seed mass spectrum, shown in Fig. 6a, is dominated by compounds in the range 238 to $300 \mathrm{Da}$. Using $\mathrm{LC}^{-\mathrm{MS}^{n}}$ these species were isolated and subjected to fragmentation, to give distinct, compound specific mass spectra, from which it was possible to assign respective identities using known library 

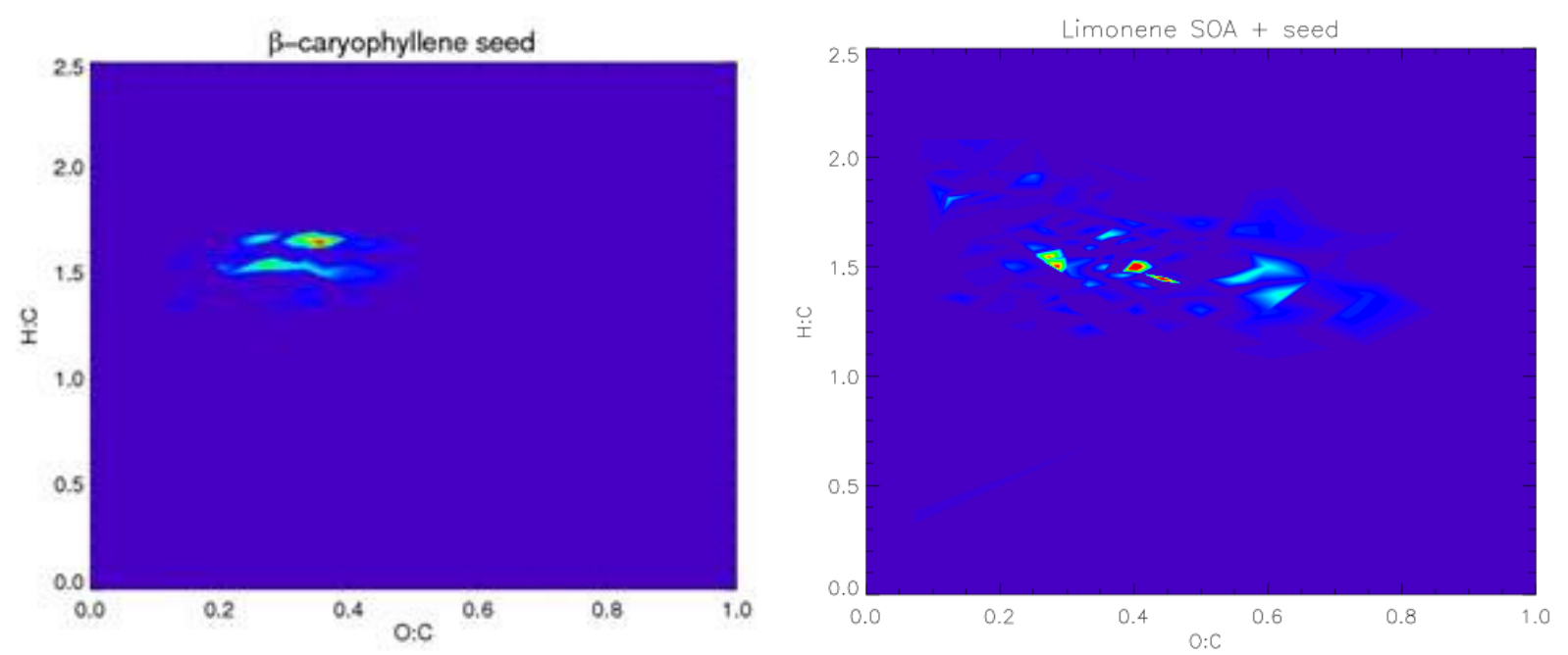

Fig. 7. 3-D Van Krevelen diagrams for the seed and limonene SOA + seed.

spectra obtained from previous $\beta$-caryophyllene SOA experiments. The distinct fragmentation patterns produced indicate that these species are known primarily first and secondgeneration products of $\mathrm{OH}$ and $\mathrm{O}_{3}$ chemistry. The major peaks are 238, 254, 270 and 284 and peak assignment and molecular identification will be provided in a companion manuscript (Alfarra et al., 2011). The limonene SOA + seed mass spectrum, shown in Fig. 5b, shows the appearance of lower molecular weight limonene oxidation products in the range 140 to $234 \mathrm{Da}$. A reduction in the intensity of the seed ions (i.e. 254,270 etc.) was observed and this is to be expected considering that the seed has been diluted in the chamber and would have been further diluted by the limonene SOA. In order to pull out the mass channels corresponding to the limonene SOA, a difference spectrum was created as shown in Fig. 6c, where peaks more abundant in the seed have negative values on the $y$-axis and peaks more abundant in the limonene + seed SOA have positive values on the y-axis. The total ion intensity was normalised to the amount of aerosol collected to allow a comparison of relative composition. The major limonene peaks detected correspond to molecular weights of 170, 186, 200 and 216 Da. The limonene SOA mass channels were subsequently investigated further using $\mathrm{LC}^{-\mathrm{MS}^{n}}$ to allow identification of limonene oxidation products in the aerosol. Using fragmentation patterns a total of 14 limonene products were identified and these are shown in Table 2.

In a previous study investigating SOA formation from the photo-oxidation of limonene, Jaoui et al. (2006) were able to identify twenty-eight different compounds in limonene SOA formed under laboratory conditions. The majority of these compounds (in the molecular weight range $86-204 \mathrm{~g} \mathrm{~mol}^{-1}$ ) were products of ring cleavage, the most abundant of which included, maleic acid (116), ketonorlimonic acid (174), ketolimonic acid (186), 5-hydroxyketolimonic acid (202), 3-carboxyheptanedioic acid (204) and 7-hydroxylimononic acid (200) (molecular weight given in parentheses). Also identified in significant abundance in the aerosol phase was the ring retaining compound 4-isopropenyl-1-methyl1-hydroxy-2-oxocyclohexane (168). Of these compounds, only ketolimonic acid and 7-hydroxylimononic acid were identified in the present study, with the latter compound being the most abundant compound in this study. A further six particle phase compounds were found to be common between this study and that of Jaoui et al., these include, limonaldheyde (168), ketolimononaldehyde (170), limonalic acid (170), limononic acid (184), 7-hydroxylimononaldehyde (184) and limonic acid (186). No ring retaining compounds were identified in the SOA of the current study.

FTICR-MS was used in negative mode to determine molecular formulae for each peak with a relative intensity greater than $0.3 \%$ of the base peak. Peaks were assumed to contain only $\mathrm{C}, \mathrm{H}$ and $\mathrm{O}$ and molecular formulae were converted into $\mathrm{H}: \mathrm{C}$ and O:C ratios. Comparison of the results with a chamber background indicated that a number of peaks were due to contamination. These were identified as saturated fatty acids from the solvents used (not seen in $\mathrm{GC} \times \mathrm{GC}$ ) and these ions were removed from any further analysis. A further manual inspection of molecular formulae was used to remove unrealistic assignments, based on maximum $\mathrm{O}: \mathrm{C}=2$ and the degree of unsaturation (rings + double bonds). Rather than investigate the detailed composition, a bulk view of the degree of oxidation was used for comparison by plotting 3 dimensional Van Krevelen diagrams, where the $\mathrm{x}$ - and $\mathrm{y}$ - axis represent the $\mathrm{O}: \mathrm{C}$ and $\mathrm{H}: \mathrm{C}$ ratios respectively and a coloured contour is used to represent peak intensity. Although peak intensity does not scale necessarily with concentration, a comparison of the relative intensity patterns is still informative. The 3-D Van Krevelen diagrams for the seed and limonene SOA + seed are shown in Fig. 7. The 
Table 2. Limonene oxidation products identified in seeded SOA.

\begin{tabular}{|c|c|c|c|}
\hline Mass of product & {$[\mathrm{M}+\mathrm{Naa}]^{+}$} & Potential molecular formula & Identified products \\
\hline 116 & 139 & $\begin{array}{c}\mathrm{C}_{5} \mathrm{H}_{3} \mathrm{O}_{3} \\
\mathrm{C}_{6} \mathrm{H}_{12} \mathrm{O}_{2}\end{array}$ & \\
\hline 154 & 177 & $\mathrm{C}_{9} \mathrm{H}_{14} \mathrm{O}_{2}$ & \\
\hline 156 & 179 & $\begin{array}{l}\mathrm{C}_{9} \mathrm{H}_{1} \mathrm{O}_{2} \\
\mathrm{C}_{8} \mathrm{H}_{12} \mathrm{O}_{3}\end{array}$ & \\
\hline 168 & 191 & $\mathrm{C}_{10} \mathrm{H}_{16} \mathrm{O}_{2}$ & \\
\hline 170 & 193 & $\mathrm{C}_{9} \mathrm{H}_{14} \mathrm{O}_{3}$ & \\
\hline 172 & 195 & $\mathrm{C}_{8} \mathrm{H}_{12} \mathrm{O}_{4}$ & \\
\hline 184 & 207 & $\mathrm{C}_{10} \mathrm{H}_{16} \mathrm{O}_{3}$ & \\
\hline 186 & 209 & $\mathrm{C}_{9} \mathrm{H}_{14} \mathrm{O}_{4}$ & \\
\hline 188 & 211 & $\mathrm{C}_{8} \mathrm{H}_{12} \mathrm{O}_{5}$ & \\
\hline 200 & 223 & $\mathrm{C}_{10} \mathrm{H}_{16} \mathrm{O}_{4}$ & \\
\hline 216 & 239 & $\begin{array}{l}\mathrm{C}_{10} \mathrm{H}_{11} \mathrm{O}_{5} \\
\mathrm{C}_{9} \mathrm{H}_{12} \mathrm{O}_{6}\end{array}$ & \\
\hline
\end{tabular}

seed plot shows a narrow $\mathrm{O}: \mathrm{C}$ range between approximately 0.1 and 0.4 with an intensity weighted mean value of 0.32 . The peaks take up a very narrow region of the Van Krevelen space. In contrast, the limonene $\mathrm{SOA}+$ seed is more spread out, with some molecules having much higher $\mathrm{O}: \mathrm{C}$ ratios. The O:C range was between 0.1 and 0.8 and the intensity weight mean was 0.37 . It is also apparent that the degree of unsaturation increases with an increase in lower $\mathrm{H}$ : $\mathrm{C}$ values. A similar increase of 0.05 is also seen in positive ionisation mode. Limonene oxidation products are therefore smaller and more polar, which will in turn increase their water solubility. This may lead to a further skewing of the O:C ratio. However, it is clear that the $\beta$-caryophyllene first generation products are still sufficiently water soluble to be extracted. An increase in O:C and decrease in $\mathrm{H}: \mathrm{C}$ should result in an increase in hygroscopicity which is indeed seen to be the case here. The data qualitatively falls within the O:C vs. GF relationship shown in Jimenez et al., 2009, however this may not be the case for other precursors.

There is some evidence for formation of limonene $+\beta$ caryophyllene oligomers. For example, a peak at $\mathrm{m} / \mathrm{z}$ 455.2654 is identified as $\mathrm{C}_{24} \mathrm{H}_{39} \mathrm{O}_{8}$, which could be a combination of a $\mathrm{C}_{10}$ (limonene) and a $\mathrm{C}_{14}(\beta$-caryophyllene) oxidation product. However, high molecular weight species $(\mathrm{m} / z>350 \mathrm{Da})$ represent less than $5 \%$ of the total peak intensity. These species are not seen in the LC-MS mass spectra and it is impossible at this time to rule out the formation of adducts during electrospray ionisation.

\section{Conclusions}

In order to improve current simulation of SOA formation, atmospherically representative seed particles are required. This work has shown that $\beta$-caryophyllene SOA generated in-situ in the chamber shows promise as a more realistic organic seed particle. It can be formed quickly, is relatively stable, cheap and easy to use. The relatively high molecular weight of the seed constituents leads to components that can be separated from the oxidation products of common VOC such as isoprene, monoterpenes and aromatics without the need for expensive isotopic labelling. Limonene SOA formation was studied using this seed and a clear change in the aerosol properties was observed during photo-oxidation and subsequent gas-particle partitioning. The $f_{44}$ from the AMS and the O:C ratio obtained from the FTICR-MS both indicate that limonene SOA is more polar and more oxidised than the seed and this resulted in an increase in hygroscopicity of the particles. This type of experiment could be used in the future to study the effect of the seed on limonene SOA composition by comparison to nucleation type experiments.

Acknowledgements. The authors gratefully acknowledge the UK Natural Environment Research Council for funding of the ACES project (NE/E011160/1) and the APPRAISE program. FTICR-MS measurements were made by Dr Ed Bergström, University of York using facilities available in the Centre of Excellence in Mass Spectrometry. The York Centre of Excellence in Mass Spectrometry was created thanks to a major capital investment through Science City York, supported by Yorkshire Forward with funds from the Northern Way Initiative.

Edited by: R. MacKenzie 


\section{References}

Aiken, A. C., DeCarlo, P. F., Kroll, J. H., Worsnop, D. R., Huffman, J. A., Docherty, K. S., Ulbrich, I. M., Mohr, C., Kimmel, J. R., Sueper, D., Sun, Y., Zhang, Q., Trimborn, A., Northway, M., Ziemann, P. J., Canagaratna, M. R., Onasch, T. B., Alfarra, M. R., Prevot, A. S. H., Dommen, J., Duplissy, J., Metzger, A., Baltensperger, U., and Jimenez, J. L.: O/C and OM/OC ratios of primary, secondary, and ambient organic aerosols with high-resolution time-of-flight aerosol mass spectrometry, Environ. Sci. Technol., 42, 4478-4485, 2008.

Alfarra, M. R., Coe, H., Allan, J. D., Bower, K. N., Boudries, H., Canagaratna, M. R., Jimenez, J. L., Jayne, J. T., Garforth, A. A., Li, S. M., and Worsnop, D. R.: Characterization of urban and rural organic particulate in the lower Fraser valley using two aerodyne aerosol mass spectrometers, Atmos. Environ., 38, 57455758, 2004.

Alfarra, M. R., Paulsen, D., Gysel, M., Garforth, A. A., Dommen, J., Prévôt, A. S. H., Worsnop, D. R., Baltensperger, U., and Coe, H.: A mass spectrometric study of secondary organic aerosols formed from the photooxidation of anthropogenic and biogenic precursors in a reaction chamber, Atmos. Chem. Phys., 6, 52795293, doi:10.5194/acp-6-5279-2006, 2006.

Alfarra, M. R., Hamilton, J. F., Wyche, K. P., Good, N., Ward, M. W., Carr, T., Lewis, A. C., Monks, P. S., and McFiggans, G. B.: The effect of photochemical ageing and initial precursor concentration on the composition and hygroscopic properties of $\beta$-caryophyllene secondary organic aerosol, Atmos. Chem. Phys. Discuss., submitted, 2011.

Bahreini, R., Keywood, M. D., Ng, N. L., Varutbangkul, V., Gao, S., Flagan, R. C., Seinfeld, J. H., Worsnop, D. R., and Jimenez, J. L.: Measurements of secondary organic aerosol from oxidation of cycloalkenes, terpenes, and m-xylene using an Aerodyne aerosol mass spectrometer, Environ. Sci. Technol., 39, 5674-5688, 2005.

Blake, R. S., Whyte, C., Hughes, C. O., Ellis, A. M., and Monks, P. S.: Demonstration of proton-transfer reaction time-of-flight mass spectrometry for real-time analysis of trace volatile organic compounds, Anal. Chem., 76, 3841-3845, 2004.

Blake, R. S., Monks, P. S., and Ellis, A. M.: Proton-Transfer Reaction Mass Spectrometry, Chem. Rev., 109, 861-896, 2009.

Corrigan, A. L., Hanley, S. W., and Haan, D. O.: Uptake of glyoxal by organic and inorganic aerosol, Environ. Sci. Technol., 42, 4428-4433, 2008.

Cubison, M. J., Alfarra, M. R., Allan, J., Bower, K. N., Coe, H., McFiggans, G. B., Whitehead, J. D., Williams, P. I., Zhang, Q., Jimenez, J. L., Hopkins, J., and Lee, J.: The characterisation of pollution aerosol in a changing photochemical environment, Atmos. Chem. Phys., 6, 5573-5588, doi:10.5194/acp-6-5573-2006, 2006.

Dommen, J., Helle|ün, H., Saurer, M., Jaeggi, M., Siegwolf, R., Metzger, A., Duplissy, J., Fierz, M., and Baltensperger, U.: Determination of the Aerosol Yield of Isoprene in the Presence of an Organic Seed with Carbon Isotope Analysis, Environ.Sci.Technol., 43, 6697-6702, 2009.

Drewnick, F., Hings, S. S., DeCarlo, P., Jayne, J. T., Gonin, M., Fuhrer, K., Weimer, S., Jimenez, J. L., Demerjian, K. L., Borrmann, S., and Worsnop, D. R.: A new time-of-flight aerosol mass spectrometer (TOF-AMS) - Instrument description and first field deployment, Aerosol Sci. Technol., 39, 637-658, 2005.

Fuzzi, S., Andreae, M. O., Huebert, B. J., Kulmala, M., Bond,
T. C., Boy, M., Doherty, S. J., Guenther, A., Kanakidou, M., Kawamura, K., Kerminen, V.-M., Lohmann, U., Russell, L. M., and Pöschl, U.: Critical assessment of the current state of scientific knowledge, terminology, and research needs concerning the role of organic aerosols in the atmosphere, climate, and global change, Atmos. Chem. Phys., 6, 2017-2038, doi:10.5194/acp-62017-2006, 2006.

Good, N., Coe, H., and McFiggans, G.: Instrumentational operation and analytical methodology for the reconciliation of aerosol water uptake under sub- and supersaturated conditions, Atmos. Meas. Tech., 3, 1241-1254, doi:10.5194/amt-3-12412010, 2010.

Grieshop, A. P., Donahue, N. M., and Robinson, A. L.: Is the gas-particle partitioning in alpha-pinene secondary organic aerosol reversible?, Geophys. Res. Lett., 34, L14810, doi:10.1029/2007GL029987, 2007.

Gysel, M., McFiggans, G. B., and Coe, H.: Inversion of tandem differential mobility analyser (TDMA) measurements, J. Aerosol Sci., 40, 134-151, 2009.

Hallquist, M., Wenger, J. C., Baltensperger, U., Rudich, Y., Simpson, D., Claeys, M., Dommen, J., Donahue, N. M., George, C., Goldstein, A. H., Hamilton, J. F., Herrmann, H., Hoffmann, T., Iinuma, Y., Jang, M., Jenkin, M. E., Jimenez, J. L., Kiendler-Scharr, A., Maenhaut, W., McFiggans, G., Mentel, Th. F., Monod, A., Prévôt, A. S. H., Seinfeld, J. H., Surratt, J. D., Szmigielski, R., and Wildt, J.: The formation, properties and impact of secondary organic aerosol: current and emerging issues, Atmos. Chem. Phys., 9, 5155-5236, doi:10.5194/acp-95155-2009, 2009.

Hamilton, J. F.: Using Comprehensive Two-Dimensional Gas Chromatography to Study the Atmosphere, J. Chromat. Sci., 48, 274282, 2010.

Hamilton, J. F., Webb, P. J., Lewis, A. C., and Reviejo, M. M.: Quantifying small molecules in secondary organic aerosol formed during the photo-oxidation of toluene with hydroxyl radicals, Atmos. Environ., 39, 7263-7275, 2005.

Hamilton, J. F., Lewis, A. C., Carey, T. J., and Wenger, J. C.: Characterization of polar compounds and oligomers in secondary organic aerosol using liquid chromatography coupled to mass spectrometry, Anal. Chem., 80, 474-480, 2008.

Inuma, Y., Muller, C., Berndt, T., Boge, O., Claeys, M., and Herrmann, H.: Evidence for the existence of organosulfates from beta-pinene ozonolysis in ambient secondary organic aerosol, Environ. Sci. Technol., 41, 6678-6683, 2007.

Intergovermental Panel for Climate Change: Climate Change 2007, 2007.

Jang, M. S., Carroll, B., Chandramouli, B., and Kamens, R. M.: Particle growth by acid-catalyzed heterogeneous reactions of organic carbonyls on preexisting aerosols, Environ. Sci. Technol., 37, 3828-3837, 2003.

Jimenez, J. L., Canagaratna, M. R., Donahue, N. M., Prevot, A. S. H., Zhang, Q., Kroll, J. H., DeCarlo, P. F., Allan, J. D., Coe, H., Ng, N. L., Aiken, A. C., Docherty, K. S., Ulbrich, I. M., Grieshop, A. P., Robinson, A. L., Duplissy, J., Smith, J. D., Wilson, K. R., Lanz, V. A., Hueglin, C., Sun, Y. L., Tian, J., Laaksonen, A., Raatikainen, T., Rautiainen, J., Vaattovaara, P., Ehn, M., Kulmala, M., Tomlinson, J. M., Collins, D. R., Cubison, M. J., Dunlea, E. J., Huffman, J. A., Onasch, T. B., Alfarra, M. R., Williams, P. I., Bower, K., Kondo, Y., Schneider, J., Drewnick, 
F., Borrmann, S., Weimer, S., Demerjian, K., Salcedo, D., Cottrell, L., Griffin, R., Takami, A., Miyoshi, T., Hatakeyama, S., Shimono, A., Sun, J. Y., Zhang, Y. M., Dzepina, K., Kimmel, J. R., Sueper, D., Jayne, J. T., Herndon, S. C., Trimborn, A. M., Williams, L. R., Wood, E. C., Middlebrook, A. M., Kolb, C. E., Baltensperger, U., and Worsnop, D. R.: Evolution of Organic Aerosols in the Atmosphere, Science, 326, 1525-1529, 2009.

Li, Y. J., Chen, Q., Guzman, M. I., Chan, C. K., and Martin, S. T.: Second-generation products contribute substantially to the particle-phase organic material produced by $\beta$-caryophyllene ozonolysis, Atmos. Chem. Phys., 11, 121-132, doi:10.5194/acp11-121-2011, 2011.

Liggio, J. and Li, S. M.: Organosulfate formation during the uptake of pinonaldehyde on acidic sulfate aerosols, Geophys. Res. Lett., 33, L13808, doi:10.1029/2006GL026079., 2006.

Lindinger, W., Hirber, J., and Paretzke, H.: An Ion/MoleculeReaction Mass-Spectrometer Used for Online Trace GasAnalysis, Int. J. Mass Spectrom., 129, 79-88, 1993.

Odum, J. R., Jungkamp, T. P. W., Griffin, R. J., Forstner, H. J. L., Flagan, R. C., and Seinfeld, J. H.: Aromatics, reformulated gasoline, and atmospheric organic aerosol formation, Environ. Sci. Technol., 31, 1890-1897, 1997.

Song, C., Zaveri, R. A., Alexander, M. L., Thornton, J. A., Madronich, S., Ortega, J. V., Zelenyuk, A., Yu, X. Y., Laskin, A., and Maughan, D. A.: Effect of hydrophobic primary organic aerosols on secondary organic aerosol formation from ozonolysis of alpha-pinene, Geophys. Res. Lett., 34, L20803, doi:10.1029/2007GL030720., 2007.

Surratt, J. D., Kroll, J. H., Kleindienst, T. E., Edney, E. O., Claeys, M., Sorooshian, A., Ng, N. L., Offenberg, J. H., Lewandowski, M., Jaoui, M., Flagan, R. C., and Seinfeld, J. H.: Evidence for organosulfates in secondary organic aerosol, Environ. Sci. Technol., 41, 517-527, 2007.
Varutbangkul, V., Brechtel, F. J., Bahreini, R., Ng, N. L., Keywood, M. D., Kroll, J. H., Flagan, R. C., Seinfeld, J. H., Lee, A., and Goldstein, A. H.: Hygroscopicity of secondary organic aerosols formed by oxidation of cycloalkenes, monoterpenes, sesquiterpenes, and related compounds, Atmos. Chem. Phys., 6, 23672388, doi:10.5194/acp-6-2367-2006, 2006.

Volkamer, R., Jimenez, J. L., San Martini, F., Dzepina, K., Zhang, Q., Salcedo, D., Molina, L. T., Worsnop, D. R., and Molina, M. J.: Secondary organic aerosol formation from anthropogenic air pollution: Rapid and higher than expected, Geophys. Res. Lett., 33, L17811, doi:10.1029/2006GL026899, 2006.

Volkamer, R., Ziemann, P. J., and Molina, M. J.: Secondary Organic Aerosol Formation from Acetylene $\left(\mathrm{C}_{2} \mathrm{H}_{2}\right)$ : seed effect on SOA yields due to organic photochemistry in the aerosol aqueous phase, Atmos. Chem. Phys., 9, 1907-1928, doi:10.5194/acp9-1907-2009, 2009.

Williams, P. I.: Construction and Validation of a DMPS for Aerosol Characterisation, 1999.

Wyche, K. P., Blake, R. S., Ellis, A. M., Monks, P. S., Brauers, T., Koppmann, R., and Apel, E. C.: Technical Note: Performance of Chemical Ionization Reaction Time-of-Flight Mass Spectrometry (CIR-TOF-MS) for the measurement of atmospherically significant oxygenated volatile organic compounds, Atmos. Chem. Phys., 7, 609-620, doi:10.5194/acp-7-609-2007, 2007.

Zhang, Q., Jimenez, J. L., Canagaratna, M. R., Allan, J. D., Coe, H., Ulbrich, I., Alfarra, M. R., Takami, A., Middlebrook, A. M., Sun, Y. L., Dzepina, K., Dunlea, E., Docherty, K., DeCarlo, P. F., Salcedo, D., Onasch, T., Jayne, J. T., Miyoshi, T., Shimono, A., Hatakeyama, S., Takegawa, N., Kondo, Y., Schneider, J., Drewnick, F., Borrmann, S., Weimer, S., Demerjian, K., Williams, P., Bower, K., Bahreini, R., Cottrell, L., Griffin, R. J., Rautiainen, J., Sun, J. Y., Zhang, Y. M., and Worsnop, D. R.: Ubiquity and dominance of oxygenated species in organic aerosols in anthropogenically-influenced Northern Hemisphere midlatitudes, Geophys. Res. Lett., 34, L13801, doi:10.1029/2007GL029979., 2007. 